\title{
An obligately anaerobic, coiled bacterium from Ace Lake, Antarctica
}

\author{
P. D. FRANZMANN ${ }^{*} \dagger$ and M. ROHDE ${ }^{2}$ \\ ${ }^{1}$ Deutsche Sammlung von Mikroorganismen (DSM) und Zellkulturen GmbH and ${ }^{2}$ Gesellschaft für Biotechnologische \\ Forschung (GBF) mbH Bereich Mikrobiologie, Mascheroderweg $1 b$, W-3300 Braunschweig, FRG
}

(Received 4 February 1991; revised 14 May 1991; accepted 4 June 1991)

\begin{abstract}
A coiled or ' $C$-shaped', Gram-negative, non-motile bacterium was isolated from the anaerobic waters of Ace Lake, an Antarctic lake of salinity similar to seawater. The strain was obligately anaerobic and lacked oxidase, catalase and respiratory lipoquinones. It fermented glucose and peptones, and formed $\mathrm{H}_{2}, \mathrm{CO}_{2}$, and butyric, acetic and formic acids as major end-products. Pyruvate was metabolized to $\mathrm{H}_{2}, \mathrm{CO}_{2}$, and acetic and formic acids. The organism had an optimum temperature for growth of $15-16^{\circ} \mathrm{C}$, and no growth occurred at $22^{\circ} \mathrm{C}$. In synthetic medium, the generation time at $1.7^{\circ} \mathrm{C}$ (in situ lake temperature) was $53 \mathrm{~h}$. The optimum $\mathrm{NaCl}$ concentration for growth was $0.3 \mathrm{M}$, with poor growth at $0.1 \mathrm{M}\left(5.8 \%\right.$, w/v). The mol $\% \mathrm{G}+\mathrm{C}$ of the DNA was $25.9 \pm 0.4 \%\left(T_{\mathrm{m}}\right)$. The bacterium could not be accommodated within current bacterial species based on phenotypic criteria. Although coiled bacteria have been previously observed in Antarctic anaerobic environments, they had not been cultivated, and their metabolic capability and possible ecological role were unknown.
\end{abstract}

\section{Introduction}

Ace Lake $\left(68^{\circ} 24^{\prime} \mathrm{S}, 78^{\circ} 11^{\prime} \mathrm{E}\right)$ is one of two known methanogenic environments on continental Antarctica (Vincent, 1988). It is meromictic and increases in salinity with depth from about $6 \%$ at the surface (in summer) to $43 \%$ in its bottom waters at $24 \mathrm{~m}$ depth (Burton, 1980). The lake water is of marine origin (Masuda et al., 1988), although the bottom waters are depleted in $\mathrm{SO}_{4}^{2-}$ (Mancuso et al., 1990) due to sulphate reduction (Burton \& Barker, 1979). Despite the low temperature of the bottom water, which is always less than $2{ }^{\circ} \mathrm{C}$ (Hand, 1980 ), it is saturated with methane, and lipid analysis of water column particulates suggests that large populations of methanogenic bacteria are present (Mancuso et al., 1990).

Attempts to isolate the methanogens using trimethylamine and antibiotics in a synthetic marine salts medium with a low yeast extract concentration produced enrichments containing a non-motile, spiral or 'C-shaped' organism in addition to a methanogenic coccus. The majority of anaerobic curved bacteria have been isolated from the rumen (Drasar, 1986) or the intestinal tract of man or animals (Kaneuchi et al., 1979; Himmelbloom \& Canale-Parola, 1989). Curved bacteria have been ob-

Present address: Australian Collection of Antarctic Microorganisms (ACAM), Institute of Antarctic and Southern Ocean Studies, University of Tasmania, Box 252C Hobart, Tasmania 7001, Australia. served in the anaerobic hypolimnia of lakes (Caldwell \& Tiedje, 1975), including Antarctic lakes of marine origin (McGuire et al., 1987), by light, fluorescence and electron microscopy, but none have previously been isolated or characterized.

\section{Methods}

Media and conditions of cultivation. Synthetic basal salts comprised the following (dissolved in 1 litre distilled water): $\mathrm{KCl}, 0.335 \mathrm{~g}$; $\mathrm{MgCl}_{2} .6 \mathrm{H}_{2} \mathrm{O}, \quad 6.0 \mathrm{~g} ; \mathrm{MgSO}_{4} .7 \mathrm{H}_{2} \mathrm{O}, 1.0 \mathrm{~g} ; \mathrm{NH}_{4} \mathrm{Cl}, 0.25 \mathrm{~g}$; $\mathrm{CaCl}_{2} .2 \mathrm{H}_{2} \mathrm{O}, 0.14 \mathrm{~g} ; \mathrm{K}_{2} \mathrm{HPO}_{4}, 0.14 \mathrm{~g} ; \mathrm{NaCl}, 18.0 \mathrm{~g} ; \mathrm{Fe}\left(\mathrm{NH}_{4}\right)_{2}$ $\left(\mathrm{SO}_{4}\right)_{2} .7 \mathrm{H}_{2} \mathrm{O}, 2.0 \mathrm{mg}$. This medium is similar in composition to the salts used by Jones et al. (1983).

For enrichment of methanogens, $1.0 \mathrm{mg}$ resazurin, $0.1 \mathrm{~g}$ yeast extract, $10.0 \mathrm{ml}$ vitamin solution (Jones et al., 1983), $10.0 \mathrm{ml}$ mineral salts solution (Jones et al., 1983), $0.1 \mathrm{ml}$ sodium acetate and $2.0 \mathrm{~g}$ trimethylammonium chloride were added to the synthetic basal salts, prepared as a more concentrated solution in $900 \mathrm{ml}$ distilled water. The solution was cooled under an atmosphere of $\mathrm{O}_{2}$-free $\mathrm{N}_{2}, 2.0 \mathrm{~g} \mathrm{NaHCO}_{3}$ was added, and the medium was dispensed under $\mathrm{N}_{2}$ and sterilized. $A$ precipitate of salts formed in the medium but this redissolved slowly. The medium was completed by the addition of $1: 20(\mathrm{v} / \mathrm{v})$ sterile stock solutions of $1.0 \%(\mathrm{w} / \mathrm{v})$ cysteine hydrochloride and $\mathrm{Na}_{2} \mathrm{~S} .9 \mathrm{H}_{2} \mathrm{O}$, and $1: 10(\mathrm{v} / \mathrm{v})$ filter-sterilized stock solution of $0 \cdot 1 \%(\mathrm{w} / \mathrm{v})$ vancomycin prepared in deoxygenated distilled water.

Maintenance medium was prepared as for the methanogen enrichment medium, except that the trace-salts solution, trimethylammonium chloride, sodium acetate, $\mathrm{Na}_{2} \mathrm{~S} .9 \mathrm{H}_{2} \mathrm{O}$ and vancomycin solution were omitted, and the yeast extract concentration was increased to $1.0 \mathrm{~g} \mathrm{l}^{-1}$. Sterile glucose $(10 \%, \mathrm{w} / \mathrm{v})$ prepared in deoxygenated distilled water was added $(1: 10, v / v)$ to complete the medium. 
Isolation. The methanogen enrichment medium $(10 \mathrm{ml})$ in Hungate tubes with an atmosphere of $\mathrm{N}_{2}$ was inoculated with $0.2 \mathrm{ml}$ amounts of an Ace Lake water sample that had been collected from a depth of $24 \mathrm{~m}$ and maintained under $\mathrm{H}_{2} / \mathrm{CO}_{2}\left(80: 20\right.$, v/v). After incubation at $10^{\circ} \mathrm{C}$ for $7 \mathrm{~d}$ the enrichments were faintly turbid and on examination by $\mathrm{UV}$ light microscopy were seen to contain a relatively large number of nonfluorescing, 'C-shaped', and spiral organisms in addition to lesser numbers of blue-fluorescing cocci. Continued incubation led to an increase in the numbers of the coccus with a decrease in the numbers of the C-shaped organism. Subculture of the enrichments at weekly intervals in the same medium (omitting vancomycin) produced cultures in which the $\mathrm{C}$-shaped bacterium was predominant. Employing the same medium gelled by the addition of $1.5 \%(\mathrm{w} / \mathrm{v})$ agar in 'agar bottles' (Braun et al., 1979) and incubated under $\mathrm{N}_{2}$ enabled isolation of the Cshaped or spiral bacterium from a single isolated colony. Subsequently, the bacterium was found to grow considerably better in maintenance medium.

Morphological, physiological and biochemical tests. Unless otherwise stated, all tests were performed by the methods of Holdeman et al. (1977) using synthetic basal salts instead of distilled water in the preparation of test media. Colony morphology was determined for well separated colonies after anaerobic growth in agar bottles on maintenance medium agar for 1 month at $10^{\circ} \mathrm{C}$. Cell morphology and motility in wet mounts, and Kopeloff's modification of the Gram reaction were determined after growth for $48 \mathrm{~h}$ in maintenance medium. Cultures grown for 1 month on maintenance medium were tested for heat- or ethanol-resistant spores (Cato et al., 1984). Susceptibility to antibiotics was tested by the broth-disc method (Holdeman et al., 1977) in maintenance medium.

The growth response of the strain to temperature in maintenance medium was determined in a Toyo temperature gradient incubator, with growth measured by increase in $\mathrm{OD}_{550}$.

For the determination of the optimum initial $\mathrm{pH}$ for growth, maintenance medium with the $\mathrm{pH}$ adjusted to 3.2 was prepared without $\mathrm{NaHCO}_{3}$. Variable volumes of a deoxygenated $7 \cdot 0 \%$ (w/v) $\mathrm{NaHCO}_{3}$ solution were added to adjust the $\mathrm{pH}$ to a range of values between $3 \cdot 2$ and 8.0. Growth was determined by measuring $\mathrm{OD}_{550}$.

Maintenance medium without $\mathrm{NaCl}$ and with all other sodium salts replaced by an equivalent weight of the corresponding potassium salts was used as the basal medium for the determination of growth response to variable $\mathrm{Na}^{+}$concentrations. Samples of basal medium $(5 \mathrm{ml})$ with $\mathrm{NaCl}$ added to $0 \cdot 1,0.3,0.5,1 \cdot 0,1 \cdot 5,2.0$ and $2.5 \mathrm{M}$ were inoculated with $0.05 \mathrm{ml}$ of a suspension of cells grown to exponential phase in maintenance medium, incubated at $4{ }^{\circ} \mathrm{C}$ and the increase in $O_{550}$ over a period of $14 \mathrm{~d}$ was determined. Stimulation of growth by the compounds listed below was determined in maintenance medium (without glucose or resazurin) by comparison of the final $\mathrm{OD}_{550}$ obtained in media with and without the test substrate after incubation for $14 \mathrm{~d}$. The compounds used were: $D(+)$-glucose, $50 \mathrm{mM}$; $D(-)$ ribose, $50 \mathrm{~mm}$; hydrogen/carbon dioxide, $80: 20(\mathrm{v} / \mathrm{v})$ [2 bar overpressure in the headspace $\left.\left(1 \mathrm{bar}=10^{5} \mathrm{~Pa}\right)\right]$; sodium formate, $20 \mathrm{mM}$; sodium acetate, $20 \mathrm{mM}$; sodium pyruvate, $20 \mathrm{~mm}$; glycerol, $20 \mathrm{~mm}$; sodium lactate, $20 \mathrm{mM}$; betaine. $\mathrm{H}_{2} \mathrm{O}, 20 \mathrm{mM}$; trimethylammonium chloride, $20 \mathrm{~mm}$; and glycine, $20 \mathrm{~mm}$.

Fermentation end-products from $D(+)$-glucose and sodium pyruvate were analysed in the spent media from the growth stimulation tests, and end-products in peptone/yeast extract synthetic basal salts (PY) and peptone/yeast extract/glucose synthetic basal salts (PYG) were determined using gas chromatography (Shimadzu). Headspace gases were determined on a $2.5 \mathrm{~m}$ long, $3 \mathrm{~mm}$ column of $100 / 120$ mesh Carbosieve (Supelco), operated isothermally at $170^{\circ} \mathrm{C}$, using $\mathrm{N}_{2}$ as the carrier gas at a flow rate of $30 \mathrm{ml} \mathrm{min}^{-1}$, with a thermal conductivity detector $\left(150^{\circ} \mathrm{C}, 75 \mathrm{~mA}\right)$. Alcohols and volatile fatty acids were separated by a $30 \mathrm{~m}$ Nukol capillary column (Supelco), with $\mathrm{H}_{2}$ as the carrier gas (linear gas flow rate, $20 \mathrm{~cm} \mathrm{~s}^{-1}$; split 100:1), and measured with a flame ionization detector. Alcohols and volatile fatty acids in ether extracts of the culture broths (Holdeman et al., 1977) were separated with a temperature programme $\left(3 \mathrm{~min}\right.$ at $75^{\circ} \mathrm{C}$, followed by heating at $32{ }^{\circ} \mathrm{C} \mathrm{min} \mathrm{m}^{-1}$ to $170^{\circ} \mathrm{C}$, with the final temperature maintained for $6 \mathrm{~min}$ ). Chloroform extracts of methyl esters of low molecular mass, non-volatile fatty acids (Holdeman et al., 1977) were determined isothermally at $140^{\circ} \mathrm{C}$. Formate in the supernatants of centrifuged, spent media was determined by the colorimetric method of Lang \& Lang (1972).

Electron microscopy. Cells grown for $3 \mathrm{~d}$ in maintenance medium at $10{ }^{\circ} \mathrm{C}$ were fixed in $3.0 \%(\mathrm{w} / \mathrm{v})$ glutaraldehyde in synthetic basal salts. Scanning electron microscopy was performed using fixed cells deposited on Nuclepore filters (Costar UK). Preparations were dehydrated with acetone, dried at the critical point of liquid $\mathrm{CO}_{2}$, sputter coated with gold $(10 \mathrm{~nm})$, and examined with a Zeiss DSM 940 scanning electron microscope.

For embedding and thin sectioning, cells were fixed with a solution of $3.0 \%(w / v)$ glutaraldehyde and $0.15 \%(w / v)$ ruthenium red in PBS ( $50 \mathrm{~mm}$ potassium phosphate buffer containing $0.9 \%, w / v, \mathrm{NaCl}$, pH 6.9) on ice. After washing with $0.15 \%(w / v)$ ruthenium red in PBS, cells were fixed for a further $3 \mathrm{~h}$ in $3.0 \%(\mathrm{w} / \mathrm{v})$ glutaraldehyde and $1.0 \%$ $(w / v)$ osmium tetroxide in PBS at room temperature. Cells were washed in PBS, embedded in $1.5 \%(\mathrm{w} / \mathrm{v})$ agar, dehydrated with acetone and embedded in Spurr's resin (Spurr, 1969). Ultrathin sections were poststained with uranyl acetate and lead citrate before examining in a Zeiss EM $10 B$ electron microscope at an acceleration voltage of $80 \mathrm{kV}$ at calibrated magnifications.

Cell components. Cell components were determined on cells grown in maintenance medium for $10 \mathrm{~d}$ at $10^{\circ} \mathrm{C}$. Cells were examined for the presence of lipoquinones (Tindall, 1990) and fatty acids (Kroppenstedt et al., 1990).

DNA base composition. DNA was isolated by the method of Marmur (1961) with the recovery of ethanol- or propan-2-ol-precipitated DNA by centrifugation, not by spooling. A treatment with cetyltrimethylammonium bromide (CTAB) (Murray \& Thompson, 1980) was required to remove contaminating polysaccharide. The $T_{\mathrm{m}}$ of each DNA was determined by thermal denaturation in $0.1 \times$ SSC $(1 \times$ SSC is $8.76 \mathrm{~g}$ $\mathrm{NaCl}$ and $4.41 \mathrm{~g}$ hydrated trisodium citrate per litre of double-distilled, deionized water) with a Gilford 2400 spectrophotometer and thermoprogrammer. DNA of known $\mathrm{G}+\mathrm{C}$ content, purified from Escherichia coli DSM $30083^{\mathrm{T}}$ (ATCC $\left.11775^{\mathrm{T}}\right)(\mathrm{G}+\mathrm{C}=51 \cdot 7$; Starr \& Mandel, 1969), was used as the standard DNA in each determination. $G+C$ content (the mean and standard error of four determinations) was determined from the formula $(G+C)_{x}=(G+C)_{s t d}+2.44$ $\left(T_{\mathrm{m}_{\mathrm{x}}}-T_{\mathrm{m}_{\mathrm{std}}}\right)$ (Sly et al., 1986).

\section{Results}

The bacterium was normally C-shaped (Fig. $1 a, c$ ), with a cell width of $0.6-0.8 \mu \mathrm{m}$. Coils (Figs $1 b$ and 2) of diameter $1.0-1.4 \mu \mathrm{m}$ and length up to $40 \mu \mathrm{m}$ (Fig. 2a) were more prevalent in young cultures and were wound anticlockwise (Fig. $2 b$ ). Cross-walls or septa were not observed in thin sections of cells in long coils (Fig. $2 c, d$ ). Straight cells were rarely observed. The cells stained Gram-negatively, and possessed a laminated cell wall with two membranes (OM and CM, Fig. $1 d$ ). The cells were non-motile and lacked flagella. Endospores were absent and the bacterium showed no heat- or alcoholresistance. 

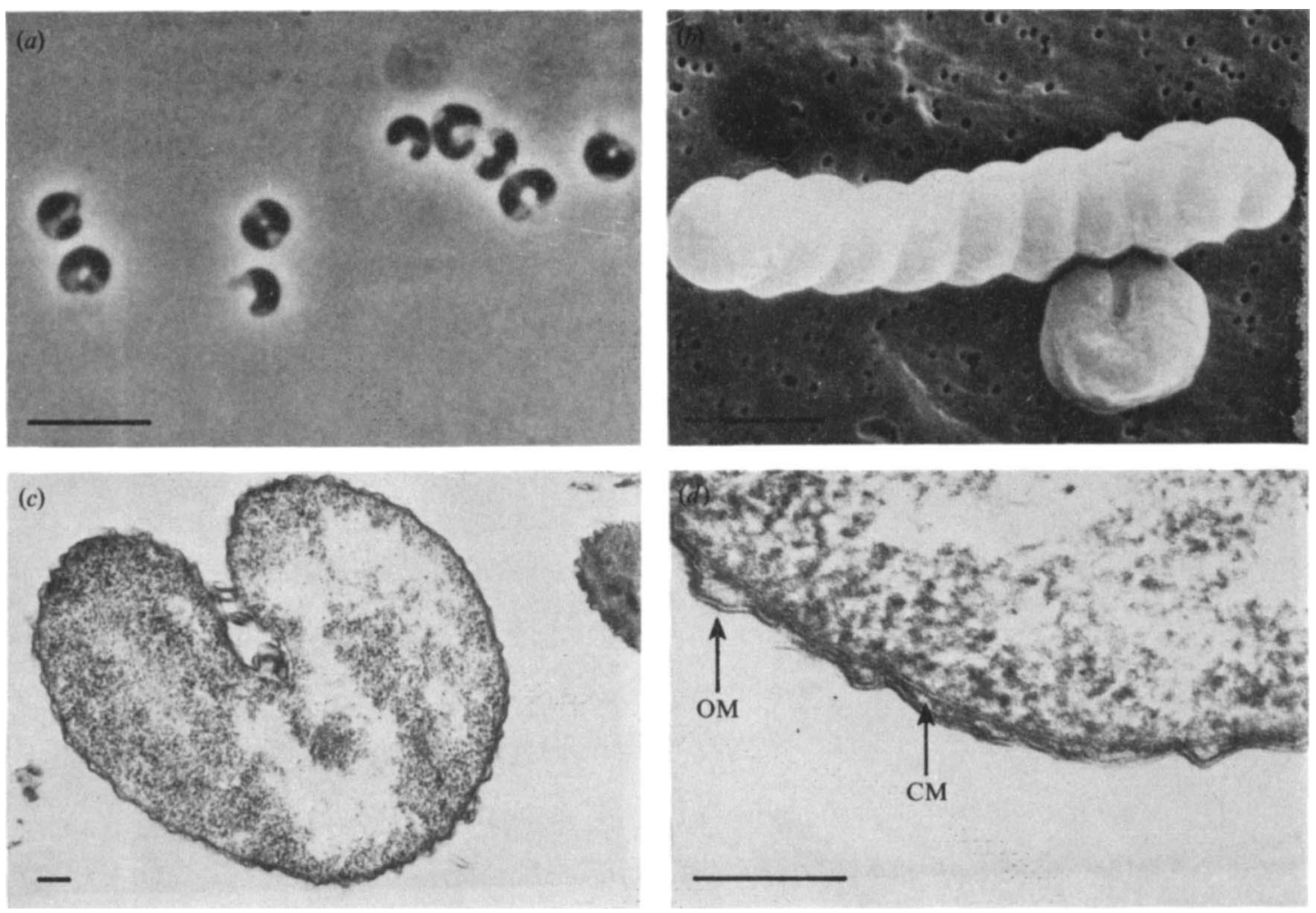

Fig. 1. Light and electron micrographs of the coiled or C-shaped isolate from Ace Lake after growth in maintenance medium for $4 \mathrm{~d}$ at $10^{\circ} \mathrm{C}$. (a) Light micrograph showing C-shaped morphology. (b) Scanning electron micrograph showing coil and C-shaped morphology. $(c, d)$ Transmission electron micrographs of ultrathin sections showing $(c)$ the $\mathrm{C}$-shape and $(d)$ cytoplasmic membrane $(\mathrm{CM})$ and outer membrane (OM). Bars; (a) $5 \mu \mathrm{m},(b) 1 \mu \mathrm{m}$ and (c,d) $0.1 \mu \mathrm{m}$.

The bacterium was an obligate anaerobe and did not grow in an anaerobic jar (Oxoid) unless the agar was poured and inoculated in an anaerobic chamber. The bacterium lacked quinones, catalase and oxidase, and it did not reduce nitrate or produce $\mathrm{H}_{2} \mathrm{~S}$. Colonies were cream to faintly yellow in colour, low convex in morphology, $2.0 \mathrm{~mm}$ in diameter and smooth after growth on maintenance medium for 1 month at $10^{\circ} \mathrm{C}$. Yeast extract stimulated but was not required for growth, but growth did not occur if the vitamin solution was omitted from the maintenance medium in the absence of yeast extract. The vitamin solution was not required if yeast extract was present.

Fermentation end-products in PY broth were $\mathbf{H}_{2}$ $(3.2 \%, v / v), \mathrm{CO}_{2}(3.5 \%, v / v)$, acetic acid $(12.5 \mathrm{mM})$, butyric acid (11.4 mM), formic acid ( $1.0 \mathrm{mM})$, propionic acid (1.1 mM) and isovaleric acid (0.4 mM).

In PYG broth, the end-products were hydrogen ( $4.9 \%$ by vol.), carbon dioxide ( $5.4 \%$ by vol.), butyric acid $(26.6 \mathrm{mM})$, acetic acid (3.2 $\mathrm{mM})$, formic acid $(1.1 \mathrm{mM})$ and propionic acid ( $0.4 \mathrm{~mm})$. In maintenance medium plus glucose, the end-products were $\mathrm{H}_{2}(23.7 \%, \mathrm{v} / \mathrm{v}), \mathrm{CO}_{2}$ $(6.8 \%, \mathrm{v} / \mathrm{v})$, acetic acid $(18.9 \mathrm{mM})$, formic acid $(10.4 \mathrm{mM})$ and butyric acid $(7.7 \mathrm{mM})$. The end-products in cooked meat medium-synthetic basal salts broth were $\mathrm{H}_{2}(5 \cdot 8 \%$, $\mathrm{v} / \mathrm{v}), \mathrm{CO}_{2}(6.8 \%, \mathrm{v} / \mathrm{v})$, butyric acid $(11.6 \mathrm{~mm})$, acetic acid (9.1 mM), formic acid (1.0 mM), with traces of isobutanol, isopentanol and isovaleric acid. Pyruvate was metabolized to $\mathrm{H}_{2}, \mathrm{CO}_{2}$, acetic acid and formic acid; no butyric acid was formed. Propionate was not produced from threonine. Glycine, trimethylamine, betaine, methanol, lactate, formate and glycerol were not utilized as sole energy sources for growth.

Acid was produced from only a limited number of the carbohydrates tested in PY broth, including D-glucoseand D-fructose, and a weak acid reaction was produced with D-mannose and D-mannitol. Acid was not produced from aesculin, hippurate, starch, D-amygdalin, salicin, D-ribose, D-raffinose, D-galactose, sucrose, L-rhamnose, glycerol, D-sorbose, D-sorbitol, erythritol, D-cellobiose, adonitol, D-lactose, dulcitol, D-melibiose, meso-inositol, glycogen, L-arabinose, maltose, D-trehalose, inulin, D-xylose and D-melezitose.

The organism was susceptible to penicillin G (2 Units $\left.\mathrm{ml}^{-1}\right)$, ampicillin $\left(4 \mu \mathrm{g} \mathrm{ml}^{-1}\right)$, tetracycline $\left(6 \mu \mathrm{g} \mathrm{ml}^{-1}\right)$, polymyxin $B$ (60 Units $\left.\mathrm{ml}^{-1}\right)$, and chloramphenicol $\left(12 \mu \mathrm{g} \mathrm{ml}^{-1}\right)$ but was resistant to bacitracin $\left(2 \mu \mathrm{g} \mathrm{ml}^{-1}\right)$, erythromycin $\left(3 \mu \mathrm{g} \mathrm{ml}^{-1}\right)$, vancomycin $\left(6 \mu \mathrm{g} \mathrm{ml}^{-1}\right)$ and kanamycin $\left(10 \mu \mathrm{g} \mathrm{ml}^{-1}\right)$.

The optimum growth temperature was $15-16^{\circ} \mathrm{C}$ with 

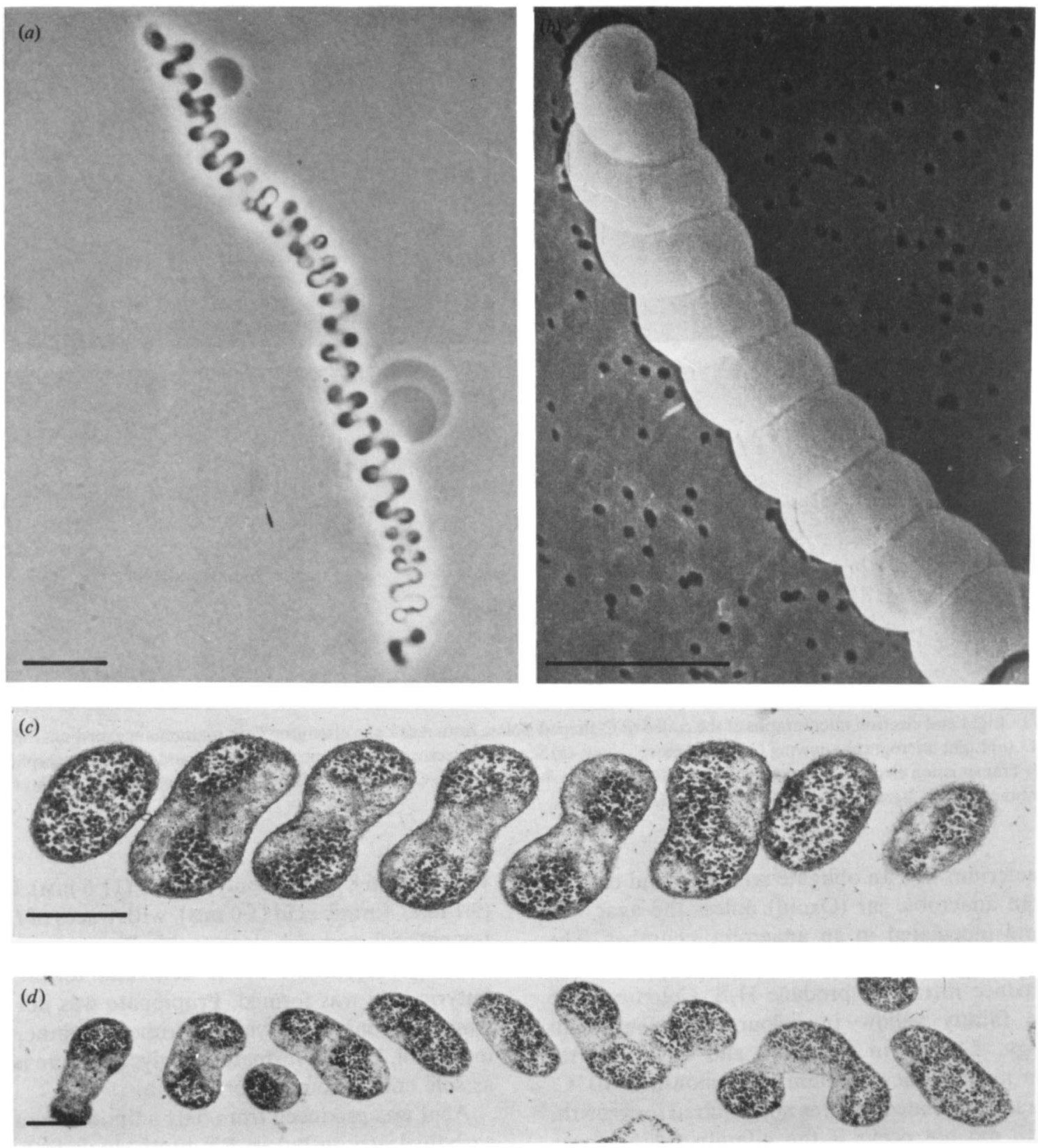

Fig. 2. Light and electron micrographs of the coiled or $\mathrm{C}$-shaped isolate from Ace Lake after growth in maintenance medium for $4 \mathrm{~d}$ at $10^{\circ} \mathrm{C}$. (a) Light micrograph and $(b)$ scanning electron micrograph of the coil wound anticlockwise. $(c, d)$ Transmission electron micrographs of ultrathin sections through coiled cells. Bars; $(a) 5 \mu \mathrm{m}$, and $(b-d) 1 \mu \mathrm{m}$.

a generation time of $6.7 \mathrm{~h}$ in maintenance medium. No growth occurred at $22^{\circ} \mathrm{C}$. At $1.7^{\circ} \mathrm{C}$, the in situ temperature of Ace Lake at $24 \mathrm{~m}$ depth, the generation time was $53 \mathrm{~h}$. The bacterium did not grow without added $\mathrm{NaCl}$ or at $\mathrm{NaCl}$ concentrations of $1.0 \mathrm{M}(c a$. $5.8 \%, \mathrm{w} / \mathrm{v}$ ) or above. The optimum $\mathrm{NaCl}$ concentration for growth was $0.3 \mathrm{M}(c a .1 .7 \%$, w/v), and poor growth occurred at $0 \cdot 1 \mathrm{M}$. The bacterium required at least $0.01 \mathrm{~mm}-\mathrm{Mg}^{2+}$ for growth. The optimal initial $\mathrm{pH}$ for growth was about $8 \cdot 0$.
The bacterium did not hydrolyse urea, gelatin, lecithin, starch, Tween 80 or aesculin. It did not produce any visible change in milk, and did not digest meat particles. Indole was not produced.

The analysis of whole cells revealed the following fatty acids in amounts greater than $0.5 \%$ of the total material extracted: $12: 0,0.81 \% ; 11: 03 \mathrm{OH}, 0.67 \% ; 12: 03 \mathrm{OH}$, $1.86 \% ; 14: 0,1.97 \% ; 14: 1$ cis-7 DMA (DMA = dimethyl acetal), $1.0 \% ; 14: 0$ DMA, $1.26 \% ; 15: 1$ iso, $1.25 \% ; 15: 2$ (isomer position unresolved). $0.62 \% ; 15: 1$ (isomer 
position unresolved), $18.88 \% ; 15: 0,2.91 \%$; unknown, $2.20 \% ; 16: 1$ cis-9, 33.44\%; 16:1 (isomer position unresolved), $1.89 \% ; 16: 0,13.99 \% ; 17: 1$ (isomer position unresolved), $2 \cdot 71 \% ; 18: 1$ (isomer position unresolved) $0.94 \%$; and $18: 0,0.83 \%$.

Although the cells possessed a Gram-negative cell wall structure and stained negatively in the Gram reaction, lysis in SDS required lysozyme pretreatment. The $\mathrm{mol} \%$ $\mathrm{G}+\mathrm{C}$ was $25 \cdot 9 \pm 0 \cdot 4$. DNA from lysed cells could not be spooled due to the large amounts of polysaccharide which precipitated with the DNA in ethanol.

\section{Discussion}

A distinctive feature of this Antarctic isolate is its morphology, reminiscent of the morphology of members of the family Spirosomaceae (Raj \& Maloy, 1990) and the ring-forming clostridia Clostridium methylpentosum (Himmelbloom \& Canale-Parola, 1989), Clostridium cocleatum and Clostridium spiroforme (Kaneuchi et al., 1979). Members of the family Spirosomaceae are obligately aerobic, contain menaquinone- 7 as a respiratory lipoquinone and have DNA with $\mathrm{G}+\mathrm{C}$ contents in the range $38-53 \%$ (Raj \& Maloy, 1990). Unlike members of the genus Clostridium, the Antarctic isolate is nonsporeforming, Gram-negative and contains hydroxy fatty acids that have not been reported for Clostridium spp. (O'Leary \& Wilkinson, 1988).

Gram-negative, curved, anaerobic rods that produce butyric acid but not succinic acid as a major end-product from glucose fermentation are currently limited to the genus Butyrivibrio. The low $\mathrm{mol} \% \mathrm{G}+\mathrm{C}$ content of the DNA of the Antarctic isolate $(25.9 \pm 0.4 \%$ ) is well below the range of $\mathrm{G}+\mathrm{C}$ contents of the DNAs of members of the genus Butyrivibrio (36-41\%; Bryant, 1984). In addition, a range of phenotypic characteristics (nonmotility, low temperature optimum, non-production of lactic acid, requirement for $\mathrm{NaCl}$ ) suggests inclusion of this bacterium in the genus Butyrivibrio may be inappropriate.

Conclusive statements regarding the taxonomy of this Antarctic bacterium requires phylogenetic analysis; however, reporting of its phenotype, source, and method of isolation at this stage will assist with further study of the non-motile, coiled bacteria of anaerobic aquatic environments, which have been regarded as "noncultivable' bacteria. As the majority of curved, obligately anaerobic, fermentative bacteria have previously been isolated from the intestine or rumen, it is not surprising that an essentially marine, cold-adapted isolate is difficult to accommodate within existing taxa, at least by phenotypic comparisons.
The bacterium was isolated from anoxic water samples collected from Ace Lake after passage through enrichments prepared for the isolation of trimethylamineutilizing methanogens. It did not grow with trimethylamine as a sole source of energy, nor did it hydrolyse any of the macromolecules tested. Presumably it has an intermediate role in the breakdown of biomass, fermenting peptides and a limited number of sugars and producing the precursors for methanogenesis and acetogenesis.

Although the bacterium grew at the in situ temperature $\left(1.7^{\circ} \mathrm{C}\right)$ and sodium ion concentration $(0.5 \mathrm{M})$ (Masuda et al., 1988) of Ace Lake bottom water, it is not perfectly adapted to this environment, as the optimal growth conditions for the bacterium in synthetic media were 15 $16{ }^{\circ} \mathrm{C}$ and $0.3 \mathrm{M}-\mathrm{NaCl}$. The numbers of $\mathrm{C}$-shaped bacteria in the water column of Ace Lake have not been determined, but in the anoxic hypolimnion of nearby Burton Lake, which has an in situ temperature of $-0.5{ }^{\circ} \mathrm{C}$ and a sodium ion concentration of $0.56 \mathrm{M}$, curved and coiled bacteria reach a population density of $10^{5}$ cells $\mathrm{ml}^{-1}$ (McGuire et al., 1987).

We thank Dr N. J. Roberts and C. A. Mancuso for their enthusiastic collaboration in the field in Antarctica, Dr R. M. Kroppenstedt for assistance with the Hewlett-Packard-FAME identification system for ester-linked fatty acids, and $\mathrm{Dr} \mathrm{H}$. Hippe for many valuable discussions.

This study was supported by the DSM. P.D.F. is supported by an Australian Research Council Fellowship and by grants and from the Antarctic Science Advisory Committee.

\section{References}

Braun, M., Schoberth, S. \& GotTschalk, G. (1979). Enumeration of bacteria forming acetate from $\mathrm{H}_{2}$ and $\mathrm{CO}_{2}$ in anaerobic habitats. Archives of Microbiology 120, 201-204.

BryaNT, M. P. (1984). Genus Butyrivibrio. In Bergey's Manual of Systematic Bacteriology, vol. 2, pp. 1376-1379. Edited by P. H. A. Sneath, N. S. Mair, M. E. Sharpe \& J. G. Holt. Baltimore: Williams \& Wilkins.

Burton, H. R. (1980). Methane in a saline Antarctic lake. In Biogeochemistry of Ancient and Modern Environments, pp. 243-251. Edited by P. A. Trudinger \& M. R. Walter. Canberra: Australian Academy of Science.

Bútion, H. R. \& BARKer, R. J. (1979). Sulphur chemistry and microbiological fractionation of sulphur isotopes in a saline Antarctic lake. Geomicrobiology Journal 1, 329-341.

Caldwell, D. E. \& Tiedje, J. M. (1975). A morphological study of anaerobic bacteria from the hypolimnia of two Michigan lakes. Canadian Journal of Microbiology 21, 362-376.

Cato, E. P., George, W. C. \& Finegold, S. M. (1984). Genus Clostridium. In Bergey's Manual of Systematic Bacteriology, vol. 2, pp. 1141-1200. Edited by P. H. A. Sneath, N. S. Mair, M. E. Sharpe \& J. G. Holt. Baltimore: Williams \& Wilkins.

DRASAR, B. S. (1986). Other anaerobes - curved and spiral organisms. In Anaerobic Bacteria in Habitats other than Man, pp. 91-100. Edited by E. M. Barmes \& G. C. Mead. Oxford: Blackwell Scientific Publications. 
HAND, R. M. (1980). Bacterial populations in two saline antarctic lakes. In Biogeochemistry of Ancient and Modern Environments, pp. 123-129. Edited by P. A. Trudinger \& M. R. Walter. Canberra: Australian Academy of Science.

Himmelbloom, B. H. \& Canale-Parola, E. (1989). Clostridium methylpentosum sp. nov.: a ring-shaped intestinal bacterium that ferments only methylpentoses and pentoses. Archives of Microbiology 151, 287-293.

Holdeman, L. V., Cato, E. P. \& Moore, W. E. C. (1977). Anaerobic Laboratory Manual, 4th edn. Blacksburg: Virginia Polytechnic Institute Anaerobic Laboratory.

Jones, W. J., PAYNTER, M. J. B. \& GUPTA, R. (1983). Characterization of Methanococcus maripaludis sp. nov., a new methanogen isolated from salt marsh sediment. Archives of Microbiology 135, 91-97.

Kaneuchi, C., Miyazato, T., Shinjo, T. \& Mitsuoka, T. (1979). Taxonomic study of helically coiled, sporeforming anaerobes isolated from the intestines of humans and other animals: Clostridium cocleatum sp. nov. and Clostridium spiroforme sp. nov. International Journal of Systematic Bacteriology 29, 1-12.

Kroppenstedt, R. M., Stackebrandt, W. \& Goodfellow, M. (1990). Taxonomic revision of the Actinomycete genera Actinomadura and Microtetraspora. Systematic and Applied Microbiology 13, 148-160.

LANG, E. \& LaNG, H. (1972). Spezifische Farbreaktion zum direkten Nachweis der Ameisensäure. Zeitschrift für Analytische Chemie 260, 8-10.

Masuda, N., Nakaya, S., Burton, H. R. \& Toril, T. (1988). Trace element distributions in some saline lakes of the Vestfold Hills, Antarctica. Hydrobiologia 165, 103-114.

MARMUR, J. (1961). A procedure for the isolation of deoxyribonucleic acid from microorganisms. Journal of Molecular Biology 3, 208-218.
Mancuso, C. A., Franzmann, P. D., Burton, H. R. \& Nichols, P. D. (1990). Microbial community structure and biomass estimates of a methanogenic antarctic lake ecosystem as determined by phospholipid analyses. Microbial Ecology 19, 73-95.

McGuire, A. J., FranzmanN, P. D. \& McMeekin, T. A. (1987). Flectobacillus glomeratus sp. nov., a curved, nonmotile, pigmented bacterium isolated from Antarctic marine environments. Systematic and Applied Microbiology 9, 265-272.

MURRAY, M. G. \& Thompson, W. F. (1980). Rapid isolation of high molecular weight plant DNA. Nucleic Acids Research 19, 4321-4325.

O'LeARY, W. M. \& WiLKINson, S. G. (1988). Gram positive bacteria. In Microbial Lipids, vol. 1. pp. 117-298. Edited by C. Ratledge \& S. G. Wilkinson. San Diego: Academic Press.

RAJ, H. D. \& MaloY, S. R. (1990). Family Spirosomaceae: gram negative ring forming aerobic bacteria. Critical Reviews in Microbiology 17, 329-364.

Sly, L. I., Blackall, L. L., Kraat, P. C., Tian-Shen, T. \& SANGKHOBOL, V. (1986). The use of second derivative plots for the determination of $\mathrm{mol} \%$ guanine plus cytosine of DNA by the thermal denaturation method. Journal of Microbial Methods 5, 139-156.

SPURR, A. R. (1969). A low viscosity epoxy resin embedding medium for electron microscopy. Journal of Ultrastructural Research 26, 3143.

Starr, M. P. \& Mandel, M. (1969). DNA base composition and taxonomy of phytopathogenic and other enterobacteria. Journal of General Microbiology 56, 113-123.

TINDALL, B. J. (1990). A comparative study of lipid composition of Halobacterium saccharovorum from various sources. Systematic and Applied Microbiology 13, 128-130.

VINCENT, W. F. (1988). Microbial Ecosystems of Antarctica. Cambridge: Cambridge University Press. 